Article

\title{
Prototype Gluten-Free Breads from Processed Durum Wheat: Use of Monovarietal Flours and Implications for Gluten Detoxification Strategies
}

\author{
Rosa Pilolli ${ }^{1, *(\mathbb{D})}$, Maria De Angelis ${ }^{2}\left(\mathbb{0}\right.$, Antonella Lamonaca ${ }^{1}$, Elisabetta De Angelis ${ }^{1}(\mathbb{D}$, \\ Carlo Giuseppe Rizzello ${ }^{2}{ }^{\circledR}$, Sonya Siragusa ${ }^{2}$, Agata Gadaleta $^{3}$, Gianfranco Mamone ${ }^{4}$ \\ and Linda Monaci ${ }^{1}$ (D) \\ 1 Institute of Sciences of Food Production, CNR-ISPA, 70126 Bari, Italy; antonella.lamonaca17@libero.it (A.L.); \\ elisabetta.deangelis@ispa.cnr.it (E.D.A.); linda.monaci@ispa.cnr.it (L.M.) \\ 2 Department of Soil, Plant and Food Science, Università degli Studi di Bari Aldo Moro, 70126 Bari, Italy; \\ maria.deangelis@uniba.it (M.D.A.); carlogiuseppe.rizzello@uniba.it (C.G.R.); sonya.siragusa@uniba.it (S.S.) \\ 3 Department of Agricultural and Environmental Sciences, Università degli Studi di Bari Aldo Moro, \\ 70126 Bari, Italy; agata.gadaleta@uniba.it \\ 4 Institute of Food Sciences, CNR-ISA, 83100 Avellino, Italy; gianfranco.mamone@isa.cnr.it \\ * Correspondence: rosa.pilolli@ispa.cnr.it
}

Received: 26 November 2020; Accepted: 11 December 2020; Published: 14 December 2020

check for updates

\begin{abstract}
In this investigation, we reported the production of prototype breads from the processed flours of three specific Triticum turgidum wheat genotypes that were selected in our previous investigation for their potential low toxic/immunogenic activity for celiac disease (CD) patients. The flours were subjected to sourdough fermentation with a mixture of selected Lactobacillus strains, and in presence of fungal endoproteases. The breads were characterized by R 5 competitive enzyme linked immunosorbent assay in order to quantify the residual gluten, and the differential efficacy in gluten degradation was assessed. In particular, two of them were classified as gluten-free $(<20 \mathrm{ppm})$ and very low-gluten content $(<100 \mathrm{ppm})$ breads, respectively, whereas the third monovarietal prototype retained a gluten content that was well above the safety threshold prescribed for direct consumption by $\mathrm{CD}$ patients. In order to investigate such a genotype-dependent efficiency of the detoxification method applied, an advanced proteomic characterization by high-resolution tandem mass spectrometry was performed. Notably, to the best of our knowledge, this is the first proteomic investigation which benefitted, for protein identification, from the full sequencing of the Triticum turgidum ssp. durum genome. The differences of the proteins' primary structures affecting their susceptibility to hydrolysis were investigated. As a confirmation of the previous immunoassay-based results, two out of the three breads made with the processed flours presented an exhaustive degradation of the epitopic sequences that are relevant for CD immune stimulatory activity. The list of the detected epitopes was analyzed and critically discussed in light of their susceptibility to the detoxification strategy applied. Finally, in-vitro experiments of human gastroduodenal digestion were carried out in order to assess, in-silico, the toxicity risk of the prototype breads under investigation for direct consumption by $\mathrm{CD}$ patients. This approach allowed us to confirm the total degradation of the epitopic sequences upon gastro-duodenal digestion.
\end{abstract}

Keywords: gluten-free; detoxification strategies; sourdough; celiac disease; epitopes; in-vitro simulated human gastroduodenal digestion 


\section{Introduction}

The wheat varietal selection undertaken by breeders in the last decades was tailored mainly to improve its technological and productivity-related traits; however, the latter resulted in a considerable impoverishment of the genetic diversity of wheat-based products available on the market. A recent debate supported the idea that such phenotype-based selection might have led to a greater immunogenicity of modern varieties, causing the increasing prevalence of celiac disease (CD) and other gluten-related disorders [1]. In line with this perspective, researchers focused on the natural diversity in the proteomic profile of cultivated and non-cultivated wheat genotypes, disclosing the correlations with their differential toxic potentials. Different analytical approaches and genotypes were investigated by independent working groups, all confirming similar key points [2-8]. First, it was assessed that there is a great variability in the immunogenic level of wheat genotypes and, although none of them can be considered safe for direct consumption by CD patients, there is an undeniable potential to select lines with lower toxicity for newly-tailored breeding programs [9-11]. Interestingly, such variability was investigated in old, landraces, and modern genotypes, reporting no correlation with the year of release, meaning that the past breeding programs did not cause an increase for immunostimulatory epitopes, as was originally speculated [1]. Indeed, the genetic improvement of wheat by breeders was mostly focused on the glutenin fraction, which is the main factor that is responsible for the dough's strength and baking characteristics $[12,13]$.

Consequently, the comprehensive proteomic characterization of wheat genotypes played a key role in providing new insight into gluten protein expression, not only supporting the drive to scout genotypes combining lower toxicity with satisfactory technological properties, but also posing convenient bases for the development of new detoxification strategies [10,14]. All of these efforts chase the long-term common objective to improve the dietary habits of people affected by CD.

The current detoxification technologies mainly rely on enzymatic-based protein hydrolysis treatment [15] or modification and sourdough-based fermentation [16,17]. Enzymes obtained from various sources (either fungi or bacteria) have been used to modify the immunogenic fraction of gluten proteins [17-19]. In particular, endopeptidases exhibit post-proline and/or post glutamine cleavage activity and, as such, can specifically degrade the epitopic sequences and minimize the CD-induced immunoreactivity of gluten proteins [20]. Microbial transglutaminases, which are typically used as texturizing agents in food products, have been used for gluten detoxification by the transamidation of lysine residues, which in turn reduces the binding ability of human leucocyte antigen (HLA) DQ2/8 [18]. The sourdough technology provides the fermentation of the wheat flour with naturally occurring lactic acid bacteria and yeasts. Previous studies have shown that specific lactobacillus strains can produce peptidases that are able to proteolytically cleave the gliadin fraction of wheat gluten [21-24]; however, the glutenin fraction was proved to be more resistant to microbial proteolysis [23,24].

Recently, we presented the detailed characterization of a Triticum turgidum wheat collection through a multidisciplinary approach [3], and we deepened the knowledge about the proteomic profile of some of the genotypes that appeared particularly promising for their gluten composition [25]. These latter were assessed in order to encrypt a reduced number of toxic/immunogenic epitopes for $C D$, whilst still providing the satisfactory rheological properties required for their perspective usability in bread or pasta.

In this investigation, three selected materials were used for the preparation of prototype breads from processed flours produced by the combination of sourdough fermentation (selected Lactobacillus strains) and enzymatic proteolysis by fungal endoproteases. The gluten content of all three genotypes was assessed by R5-competitive enzyme linked immunosorbent assay (ELISA), and a variable hydrolysis degree was accomplished for each flour. In order to increase the understanding of this experimental evidence, we carried out a detailed proteomic characterization by high resolution mass spectrometry (HR-MS). In particular, the total proteins were extracted by a strongly denaturing and reducing buffer solution that was previously optimized [26], and the discovery HR-MS analysis was carried out on both the high and low molecular weight fractions in order to disclose the amino acid sequence of the hydrolyzed and resistant peptides. Finally, the occurrence of intact CD epitopes was investigated 
in-silico by querying on-line databases containing all of the known CD epitopes [27]. Interestingly, for the first time, a proteomic characterization benefited from the full sequencing of the Triticum turgidum ssp. durum genome [28], providing new insights and discussions.

\section{Materials and Methods}

\subsection{Plant Materials and Proteolytic Mixture}

Three wheat genotypes were selected for the present investigation: (1) Colosseo (Triticum turgidum ssp. durum), (2) Neolatino (Triticum turgidum ssp. durum), and (3) PI 56263 (Triticum turgidum ssp. turgidum). The wheat genotypes were grown in the experimental field "A. Martucci" of the Department of Soil, Plant and Food Sciences at Valenzano (Bari, Italy) in 2017, in a randomized complete block design. The full details of the agronomic practices are described elsewhere [3].

Three lactic acid bacteria (LAB) strains belonging to the Culture Collection of the Department of Soil, Plant and Food Science were selected for the present investigation, according to their specific proteolytic activity: Lactobacillus sanfranciscensis GF1, Lactobacillus plantarum GF2, and Lactobacillus casei GF3. The LAB strains were cultivated for $24 \mathrm{~h}$ at $30^{\circ} \mathrm{C}$ on MRS (de Man, Rogosa \& Sharpe broth) in addition to maltose and yeast, both at $5 \mathrm{~g} / \mathrm{L}$. Commercial proteases from Aspergillus oryzae (500,000 hemoglobin units on the tyrosine basis/g; enzyme 1 [E1]) and Aspergillus niger (3000 spectrophotometric acid protease units/g; enzyme 2 [E2]), which are routinely used for bakery applications, were supplied by BIO-CAT Inc. (Troy, VA). The fungal protease Veron PS ( $25 \mathrm{~g} / 100 \mathrm{~kg}$ of flour) and the protease Veron HPP (from Bacillus subtilis) (10 g/100 kg of flour) were supplied by AB Enzymes.

\subsection{Prototype-Breads Preparation}

Sourdoughs were produced from each T. turgidum genotype by mixing $30 \%(w / w)$ flour with $70 \%$ $(w / w)$ tap water, this latter containing a suspension of the pooled LAB strains (L. sanfranciscensis GF1, L. plantarum GF2, L. casei GF3) at the density of 9 log colony forming unit $/ \mathrm{g}(\mathrm{CFU} / \mathrm{g})$. Before the sourdough fermentation, a mixture of the commercial enzymatic preparations was added. In particular, E1 and E2 were added at $200 \mathrm{ppm}$, Veron PS was added at $25 \mathrm{~g} / 100 \mathrm{~kg}$ of flour, and Veron HPP was added at $10 \mathrm{~g} / 100 \mathrm{~kg}$ of flour. The doughs were incubated for $48 \mathrm{~h}$ at $37^{\circ} \mathrm{C}$, with stirring conditions of ca. $200 \mathrm{rpm}$.

Gluten-free breads (dough yield (DY) $=$ dough weight $\times 100 /$ flour weight, of 200) were prepared using rice and corn flours (ratio 1:1 of dry matter). The sourdough was added into the final recipe of the bread (30\% of the total amount of dough). Baker's yeast was added at the percentage of $2 \% w / w$, corresponding to a final cell density of about $9 \log \mathrm{CFU} / \mathrm{g}$ in all of the breads. The doughs were mixed at $60 \mathrm{~g}$ for $5 \mathrm{~min}$ with an IM 5-8 high-speed mixer (Mecnosud, Flumeri, Italy), and the fermentation was carried out at $30{ }^{\circ} \mathrm{C}$ for $1.5 \mathrm{~h}$. All of the breads were baked at $220{ }^{\circ} \mathrm{C}$ for $30 \mathrm{~min}$ (Combo 3, Zucchelli, Verona, Italy). The resulting breads were coded as HYD-1 (hydrolysed Colosseo flour), HYD-2 (hydrolysed Neolatino flour), and HYD-3 (hydrolysed PI 56263 flour). The control breads were prepared using untreated flours (not subjected to sourdough fermentation and without protease addition) in the same ratio and according to the same production protocol. The resulting samples were coded as CTRL-1 (Colosseo flour), CTRL-2 (Neolatino flour), and CTRL-3 (PI 56263 flour).

After baking, the breads were manually crumbled, collected in a flat box and left at $37^{\circ} \mathrm{C}$ overnight for dryness. Afterwards, the crumbles were ground with a laboratory blender (Sterilmixer 12, VWR International PBI, Milano, Italy) for $30 \mathrm{~s}$ at 16,000 rpm (CHECK SPEED 10). The minces were carefully mixed in a plastic bag for $5 \mathrm{~min}$ for homogeneity, and then manually sieved with a $1 \mathrm{~mm}$ mesh, aliquoted, sealed under vacuum, and stored at $-20^{\circ} \mathrm{C}$ until their use. Three independent batches of sourdoughs and breads were produced and analysed.

\subsection{Gluten Quantification by Immune-Enzymatic Assay (R5 Competitive ELISA)}

The analysis of the gluten was carried out using the RIDASCREEN ${ }^{\circledR}$ Gliadin competitive (Art. No. R7021, R-Biopharm) kit, according to the producer's instructions. In detail, two protein extracts 
were prepared for each prototype bread, and each extract was assayed on two different wells of the microplate. For the control samples (CTRL-1, CTRL-2, and CTRL-3) and the processed sample (HYD-2), an additional dilution factor of 1:200 in 60\% ethanol was applied in order to allow proper gluten quantification within the validated dynamic range.

\subsection{Proteomic Characterization by High Resolution Tandem Mass Spectrometry (HR-MS/MS) Analysis}

\subsubsection{Sample Preparation Protocol}

Two hundred milligrams of the minces from all of the prototype breads were extracted with $5 \mathrm{~mL}$ previously-optimized sample buffer, under strong denaturant and reducing conditions (100 mM Tris $\mathrm{HCl} \mathrm{pH} \mathrm{8.5,} 8 \mathrm{M}$ urea and $2 \% \mathrm{v} / v$ dithiothreitol) [26]. After the buffer's addition, the mixture was shaken with a vortex for $2 \mathrm{~min}$ and subjected to a probe-based ultrasound-assisted extraction, as has previously been described [29]. Afterwards the samples were centrifuged for $10 \mathrm{~min}$ at $3500 \mathrm{~g}$ and the supernatants were collected.

The total protein amount of the supernatant was quantified using a commercial kit for colorimetric assays (Quick Start ${ }^{\mathrm{TM}}$ Bradford protein assay, Bio-rad Laboratories).

Aliquots of such extracts $(0.5 \mathrm{~mL})$ were loaded on $3 \mathrm{kDa}$ cut-off membranes for ultra centrifugal filtration (Amicon ${ }^{\circledR}, 3 \mathrm{kDa}$ ultra centrifugal filters, Merck), which were properly activated with MilliQ water according to the instructions of the provider. The permeate fraction containing the low molecular weight compounds $(<3 \mathrm{kDa})$ was labelled and referred to as the LMW fraction of the protein extract.

In addition, a $30 \mu \mathrm{L}$ aliquot of the extract was diluted 1:10 with chymotrypsin optimized digestion buffer (Tris $\mathrm{HCl} 100 \mathrm{mM}$, pH 8.0 added with $10 \mathrm{mM}$ of $\mathrm{CaCl}_{2}$ ), for a final volume of $300 \mu \mathrm{L}$. Such samples were thermally denaturated ( $15 \mathrm{~min}$ incubation at $95^{\circ} \mathrm{C}$ under shaking, $500 \mathrm{rpm}$ ), chemically reduced (added $30 \mu \mathrm{L}$ of dithiotreitol $50 \mathrm{mM}, 30 \mathrm{~min}$ incubation at $60{ }^{\circ} \mathrm{C}$ under shaking $500 \mathrm{rpm}$ ), and alkylated (added $60 \mu \mathrm{L}$ of iodacetamide $100 \mathrm{mM}, 30 \mathrm{~min}$ incubation at RT, in the dark). The enzymatic digestion was then started by the addition of $6 \mu \mathrm{L}$ chymotrypsin solution, $0.5 \mu \mathrm{g} / \mu \mathrm{L}$ in $1 \mathrm{mM} \mathrm{HCl}$ (minimum enzyme/protein ratio of 1:20 for each sample). The digestion was left overnight at $37^{\circ} \mathrm{C}$ under shaking (500 rpm) and stopped after $15 \mathrm{~h}$ by acidification with $5 \mu \mathrm{L} \mathrm{HCl} 6 \mathrm{M}$. The digests were centrifuged at 13,000 rpm for $10 \mathrm{~min}$. The resulting peptide pool was referred to as the high molecular weight (HMW) digests.

\subsubsection{Discovery HR-MS/MS Analysis and Protein/Peptides Identification}

Micro-HPLC-MS/MS analyses were performed on an Ultimate 3000 UHPLC system coupled to a hybrid quadrupole-Orbitrap ${ }^{\mathrm{TM}}$ mass spectrometer Q-Exactive Plus (Thermo Fisher Scientific, San Josè, CA, USA). The chromatographic separation was accomplished with an Acclaim PepMap100, C18 column, $(3 \mu \mathrm{m}, 100 \AA, 1 \times 150 \mathrm{~mm})$. The untargeted HR-MS/MS analyses were performed using the Full-MS/dd-MS2 analysis mode; all of the instrumental details are described elsewhere [3,25]. The raw data were processed by Proteome Discoverer v.2.1 sp1 (Thermo Fisher Scientific) for peptide/protein identification. The Sequest HT searching algorithm was applied against a customized database including all of the entries related to Triticum taxonomy (https://www.uniprot.org/, accessed on 27 February 2020, total of 335,217 accessions including the Triticum turgidum ssp. durum reference proteome UP000324705). The processing workflow was set as follows: non-specific cleavage; mass tolerance on the precursor and fragment ions $10 \mathrm{ppm}$ and $0.02 \mathrm{Da}$, respectively; precursor mass 300-6000 Da; minimum peak count 3; dynamic modifications: methionine-oxidation, glutamine/asparagine-deamidation, N-terminal glutamine cyclization to pyroglutamate, $\mathrm{N}$-terminal protein acetylation; and static modifications: cysteine-carbamidomethylation (only for the HMW-fraction). The peptide list obtained as the software output was filtered for the best results reliability according to the following criteria: at least 2 peptide-spectrum matches (PSMs) for each sequence, and unambiguous PSM only. 


\subsection{In Vitro-Simulated Human Gastroduodenal Digestion Experiments}

The minces of the breads obtained from the processed flours Colosseo (HYD-1) and PI 56263 (HYD-3) were subjected to additional experiments of in-vitro simulated human gastroduodenal (GD) digestion. The standardized static model proposed by Minekus et al. in 2014 [30] was applied to $1 \mathrm{~g}$ mince for each sample. After the GD digestion, the samples were purified by solid phase extraction (SPE) according to protocols reported elsewhere [3,25], with few modifications. In particular, the SPE was carried out on C18 disposable cartridges, loading $1 \mathrm{~mL}$ sample. After elution with $90 \%$ methanol, the samples were dried and resuspended in $100 \mu \mathrm{L}$ of $90: 10$ water/acetonitrile $+0.1 \%$ formic acid to achieve a pre-concentration factor of 10 times.

The samples were analysed in the manner already described in Section 2.4.2, with a few modifications related to the software-based data processing. The GD digestion was carried out with a complex enzyme mixture; as such, no specificity was expected for the proteolytic cleavage, and the 'no enzyme' option was set for the data analysis. Moreover, the carbamidomethylation of the cysteine residues was excluded because the reduction/alkylation step was not included in this protocol.

\section{Results and Discussion}

\subsection{Prototype Bread Sample Preparation}

Maize, rice, sorghum, and pseudo-cereal flours, as well as their corresponding fractionated starches, are used as the main substitutes of wheat in celiac product formulations [31,32]. Among these, rice flour is the most commonly used in gluten-free (GF) bread formulations due to the fact that it is widely available and inexpensive, and is characterized by an appreciated sensory profile. It is white in colour, bland in taste, easily digested, and hypoallergenic. Despite these advantages, rice flour presents technological limitations in bread-making due to the poor functional properties of its proteins, as is also observed for all of the other GF cereal flours [33,34].

Besides the unavoidable structural and sensory problems related to the use of GF flour instead of wheat, the nutritional features of GF products are also widely debated [35]. Indeed, it was reported that GF commercial products are often characterized by very low dietary fiber content and excess calories [36,37]. Since the scientific community has correlated the unbalanced GF diet to the increasing occurrence of chronic degenerative pathologies, the necessity to improve the nutritional value of the GF products has already been highlighted [37,38]. From this point of view, sourdough fermentation was reported as an effective tool for the improvement of the sensory, technological, and especially nutritional and functional properties of GF baked goods [39]. Different research groups [39-43] have demonstrated that a biotechnological protocol including the use of selected sourdough lactobacilli can lead to a complete hydrolysis of gluten during the long-time fermentation of wheat flour [39]. Long-term in vivo trials have confirmed that experimental baked goods that were made with detoxified fermented flours were completely safe [41,42], thus leading to the industrialization of the process [44].

Based on the above-mentioned knowledge, a biotechnological process based on the use of three selected LAB and commercial proteases was used in this work in order to detoxify the gluten form the flours obtained from three different wheat genotypes. L. sanfranciscensis GF1, L. plantarum GF2, and L. casei GF3, previously isolated from wheat sourdoughs, were selected based on their protease and peptidase activities (data not shown), and were used as a mixed starter. It is well known that LAB possess a very complex peptidase system [45], although this is not a unique strain that may possess the entire pattern of peptidases needed for the hydrolysation of all of the peptides in which Pro residue are present, such as in gluten sequences. The role of the fungal proteases is retained essentially in the primary proteolysis, by releasing various sizes of polypeptides, which are thus available for the bacterial degradation.

As such, sourdoughs were used to make the GF prototype bread including rice and corn flours as the main ingredients. As we were aiming for a biochemical investigation, the prototype formulation did not include the structuring or flavouring agents commonly required to obtain products that are designed for commercial use or consumption [36]. 


\subsection{Gluten Quantitation and Detoxification Efficiency}

The quantitation of gluten in fermented/hydrolysed foods poses analytical challenges in method development and validation because the peptide patterns deriving from proteolysis can dramatically differ according to the fermentation/hydrolysis processes applied; theoretically, the relevant calibrants required for quantitative purposes should change accordingly. In addition, the regulatory threshold of $20 \mathrm{ppm}$ was based on studies examining the immunopathogenicity of intact gluten [46,47]; whether the immunoreactivity/toxicity potential is the same for gluten peptides produced during fermentation is unknown. The protein/peptide profiles generated during the fermentation of different foods is dependent on numerous parameters, such as ingredients, time, temperature, and selected microrganisms and/or enzymes; therefore, it is an unrealistic goal to generalize the profile of different fermented/hydrolysed foods.

Until now, ELISA kits have routinely been used for the detection and quantitation of gluten in food and, in particular, the competitive assays that recognize a single epitope represent the preferential choice for the detection of immunoreactive peptides in hydrolysed foods. Competitive assays based on R5 (Ridascreen ${ }^{\circledR}$ Gliadin Competitive by R-Biopharm) and G12 (GlutenTox ${ }^{\circledR}$ Competitive by Biomedal Diagnostics) monoclonal antibodies are commercially available. The R5 competitive ELISA kit grounds its specificity on the R5 monoclonal antibody, which was specifically raised against the peptide sequences QQPFP, QQQFP, LQPFP, QLPFP, and includes pepsin/trypsin enzimatic digested prolamins from wheat, rye, and barley as calibrants. It features the first action approval by the association of official analytical chemists (AOAC) for the official method of analysis (OMA 2015.05) and as such, it represents the best choice currently available on the market for hydrolysed gluten quantification, and for a preliminary estimation of the efficacy in gluten detoxification strategies [48].

All of the prototypes prepared in this investigation were subjected to R5 immunoassay for residual gluten quantification. Gliadin fractions of both the hydrolysed and control samples were extracted with $60 \%$ ethanol, according to the kit's instructions. The set dynamic range for the assay was between 10 and $270 \mathrm{ng} / \mathrm{mL}$, corresponding to $10-270 \mathrm{ppm}$ of the gluten in the food matrix. Based on this, the three CTRL samples expected to contain a gluten concentration above the kit's upper limit were subjected to an additional dilution (1:200) of the protein extract before performing the assay, in order to allow a proper quantification within the validity range of the calibration curve. Notably, all of the tested samples were properly quantified except for the HYD-2 samples, which generated an out of range result ([gluten] $>270 \mathrm{ppm}$ ). The assay was repeated for this sample by applying an increasing dilution factor of the gliadin extract in order to reach the proper levels for the gluten quantification. The averaged results are reported in Table 1 .

Table 1. Overview of R5-competitive enzyme linked immunoassay (ELISA) analysis carried out on the prototype breads ( $n=2$ independent extracts/bread and $n=2$ assay replicates/extract).

\begin{tabular}{cccc}
\hline Sample Code & Gluten $[\mathbf{m g} / \mathbf{k g}]$ & Relative Standard Deviation $\%$ & Degradation Efficiency \\
\hline HYD- ${ }^{*}$ & $11.3 \pm 1.3$ & $11 \%$ & $99.5 \%$ \\
CTRL-1 * & $2490 \pm 80$ & $3 \%$ & \\
HYD-2 * & $7600 \pm 700$ & $9 \%$ & $22.0 \%$ \\
CTRL-2 * & $9700 \pm 1100$ & $11 \%$ & \\
HYD-3 & $36 \pm 7$ & $19 \%$ & $99.6 \%$ \\
CTRL-3 & $9800 \pm 1100$ & $11 \%$ & \\
\hline
\end{tabular}

* HYD: processed bread; CTRL control bread; sample 1: bread produced with Colosseo flour; sample 2 bread produced with Neolatino flour; sample 3: bread produced with PI 56263 flour.

By comparing the CTRL and HYD samples for each wheat genotype, a reduced amount of gluten was assessed to be present in all of the three prototype breads from the hydrolysed flours; the reduction was directly ascribed to the proteolytic activity of the enzymatic/microbial mixture designed for the current investigation. However, the fermentation process-applied under comparable conditions to the three selected wheat flours-provided a variable efficacy in gluten degradation depending on 
the specific genotype. In particular, the sample prepared by the sourdough fermentation of Colosseo flour (HYD-1) resulted in a final prototype bread which can be labelled as GF, due to residual gluten content below the $20 \mathrm{ppm}$ threshold limit $(11.3 \pm 1.3 \mathrm{ppm})$. The prototype bread HYD-3, prepared with PI 56263 flour, presented a residual gluten concentration of $36 \pm 7 \mathrm{ppm}$, which is referred to as 'very low gluten content' ( $20 \mathrm{ppm}<$ [gluten] $<100 \mathrm{ppm}$ ). In both cases, the gluten degradation efficiency was assessed to be very high $(\geq 99.5 \%)$, and the final prototype breads could potentially be included in the diet of CD patients. On the contrary, the HYD-2 sample prepared using Neolatino flour maintained a high level of residual gluten $(7600 \pm 700 \mathrm{ppm})$, and was thus not acceptable for direct consumption by CD patients. Notably, in this investigation, it was proven for the first time that the efficiency of gluten detoxification strategies are strictly related to the specific protein profile of the wheat flour. Interestingly, the genotype-depending efficiency reported here poses specific challenges to food technologists because it constrains the validity of all of the previous investigations dealing with gluten hydrolysis by the enzymatic treatment and/or sourdough fermentation of the specific flours on which they were developed and validated. In order to increase the understanding of this experimental evidence, we carried out a detailed proteomic characterization using high resolution tandem mass spectrometry (HR-MS/MS).

\subsection{Proteome Profiling and Resistant Epitope Matching}

For the proteomic characterization of prototype samples, a comprehensive protein extraction was carried out under previously optimized conditions [26]. A strong denaturing and reducing buffered solution was prepared and applied to all of the bread minces (CTRL and HYD). The total protein extracts were quantified using a commercial kit with two analytical replicates and two technical replicates. Figure 1 summarizes the averaged results. Notably, all of the extracts derived from the processed flours (HYD-1, HYD-2, HYD-3) presented a protein concentration lower than the relevant control samples (CTRL-1, CTRL-2, CTRL-3, respectively). The rationale of this experimental evidence was found in the working principle of the colorimetric assay. Indeed, as a Coomassie dye-based assay, the development of colour is associated to the instauration of Van der Waals forces, and hydrophobic interactions between the dye and specific side chains of the proteins. Peptides or oligopeptides with low molecular weights $(<3 \mathrm{kDa})$ cannot provide such an interaction and do not produce colour in reaction to Coomassie dye reagents. Therefore, the results reported in Figure 1 presented an indirect confirmation of the protein hydrolysis occurring in all of the hydrolysed flours at different degrees.

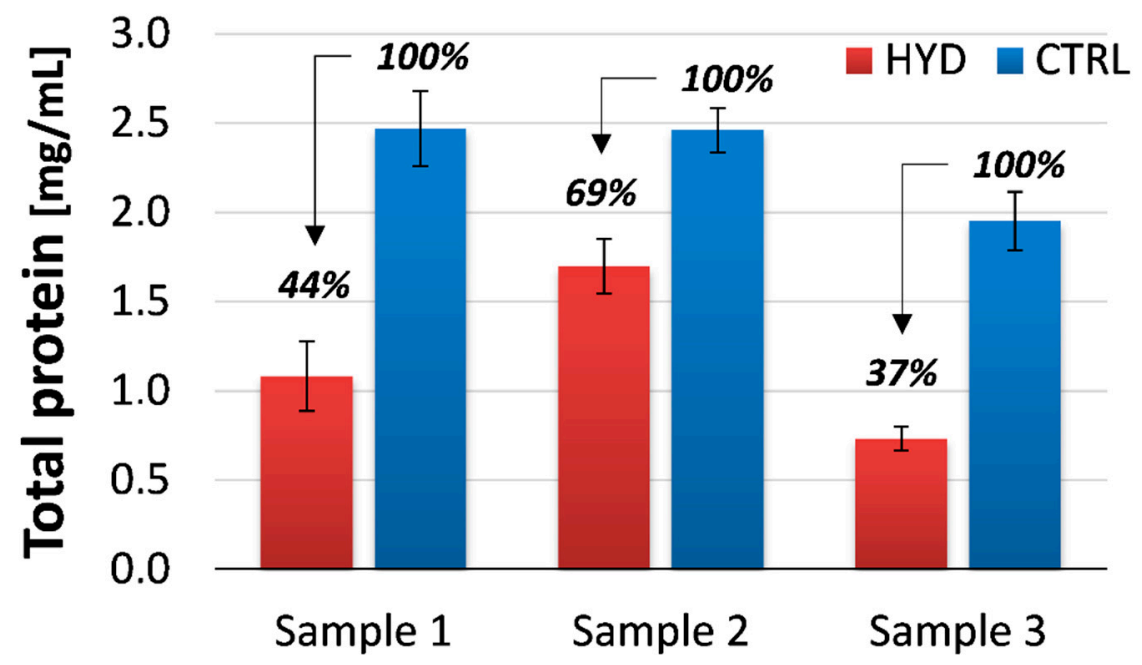

Figure 1. Protein quantification of the model breads by Bradford colorimetric assay carried out on the total protein extracts. 
In order to characterize the low-molecular weight (LMW) fraction resulting from flour hydrolysis, the ultrafiltration of the total protein extracts on cut-off membranes was applied, with a size limit of $3 \mathrm{kDa}$. The permeate fraction (LMW) was directly analysed by untargeted HR-MS/MS for the sequence identification. For comparison, we applied the same protocol and analysis to both the hydrolysed and control breads, notwithstanding the absence in the latter of the fermentation/hydrolysis step.

The HR-MS/MS analysis was carried out in data dependent acquisition mode, and the fragmentation spectra were processed via commercial software for sequence identification against a customized database containing all of the protein accessions currently assigned to the Triticum taxonomy. Notably, such a database was significantly extended compared to our previous investigation [25], because it was populated with the whole proteome of Triticum turgidum subsp. durum (taxonomy ID 4567), which was made publicly available after the full sequencing of its genome [28]. Therefore, we expected, for this investigation, a wide coverage and good reliability in the peptide and protein sequence identification, benefitting from the T. turgidum subsp. durum reference proteome. Given the high complexity of the proteolysis accounted for by the simultaneous microbial and fungal activities, a non-specific cleavage was set for the database indexing. As was expected, very few peptides were detected in the LMW fraction of the three control samples, confirming that all of the sequences identified in samples HYD-1, HYD-2, and HYD-3 were directly ascribed to the detoxification strategy devised and carried out on these samples. In particular, 312, 242 and 384 peptides were detected in samples HYD-1, HYD-2, and HYD-3, respectively, as is reported in Table 2.

Table 2. Summary of the peptides identified by the discovery HR-MS/MS analysis of the model breads prepared with monovarietal durum wheat flour and subjected (HYD) or not (CTRL) to sourdough and enzymatic fermentation.

\begin{tabular}{|c|c|c|c|c|c|c|c|c|}
\hline Sample Type & Peptides Co & & HYD-1 & CTRL-1 & HYD-2 & CTRL-2 & HYD-3 & CTRL-3 \\
\hline \multirow{4}{*}{$\begin{array}{l}\text { Low molecular } \\
\text { weight }(\mathrm{LMW}) \\
\text { fraction, }<3 \mathrm{kDa}\end{array}$} & \multirow{2}{*}{\multicolumn{2}{|c|}{$\begin{array}{l}\text { total identified } \\
\text { hazard peptides with intact celiac } \\
\text { disease }(C D) \text { epitope }\end{array}$}} & 312 & 4 & 242 & 4 & 384 & 7 \\
\hline & & & - & - & 7 & - & 6 & - \\
\hline & Protein distribution of & $\gamma$-gliadin & - & - & 7 & - & 6 & - \\
\hline & hazard peptides* & $\omega$-gliadin & - & - & 2 & - & 1 & - \\
\hline \multirow{8}{*}{$\begin{array}{l}\text { High molecular } \\
\text { weight (HMW) } \\
\text { fraction, } \\
\text { chymotrypsin } \\
\text { digest }\end{array}$} & \multirow{2}{*}{\multicolumn{2}{|c|}{$\begin{array}{c}\text { total identified } \\
\text { hazard peptides with intact CD } \\
\text { epitope }\end{array}$}} & 614 & 1394 & 1097 & 1671 & 663 & 1599 \\
\hline & & & - & 69 & 46 & 83 & 1 & 92 \\
\hline & \multirow{6}{*}{$\begin{array}{l}\text { Protein distribution of } \\
\text { hazard peptides * }\end{array}$} & $\alpha$-gliadin & - & 14 & 11 & 19 & - & 23 \\
\hline & & $\gamma$-gliadin & - & 22 & 20 & 34 & - & 32 \\
\hline & & $\omega$-gliadin & - & 14 & 7 & 14 & 1 & 24 \\
\hline & & LMW-glutenin & - & 25 & 11 & 21 & - & 12 \\
\hline & & HMW-glutenin & - & 1 & 1 & 1 & - & 1 \\
\hline & & $\begin{array}{l}\text { AAI domain } \\
\text { containing }\end{array}$ & - & 8 & 9 & 11 & - & 21 \\
\hline
\end{tabular}

* Several sequences were shared among the different accessions.

Figure 2 presents an overview of the detected peptides according to their specific features. In particular, the size distribution was reported in Figure 2a, expressed as the number of amino acid (AA) residues. For all three samples (HYD-1, HYD-2, HYD-3), most of the identified sequences resulted in very short fragments (6-8 AA) that featuring a length below the minimum peptide-binding register (cut-off 9 AA) did not pose any toxicity risk in CD patients [27]. Notably, the previous comments about a differential hydrolysis accounted for by the microbial/enzymatic activity on the three monovarietal flours was consistently supported by such a preliminary MS investigation on the LMW fraction. Indeed, also in this experiment, the sample HYD-2 results showed that it was less affected by protein degradation than the other two samples, resulting in a lower count of identified peptides, especially as for the shortest fragments. In Figure $2 b$, the peptide distribution among the different proteins is displayed, with particular attention to the storage proteins that were individually counted, whereas all of the metabolic and other water-soluble proteins were listed in the general category 'others', 
and all of the accessions that were not directly ascribable to the previous categories were labelled as 'uncharacterized'.
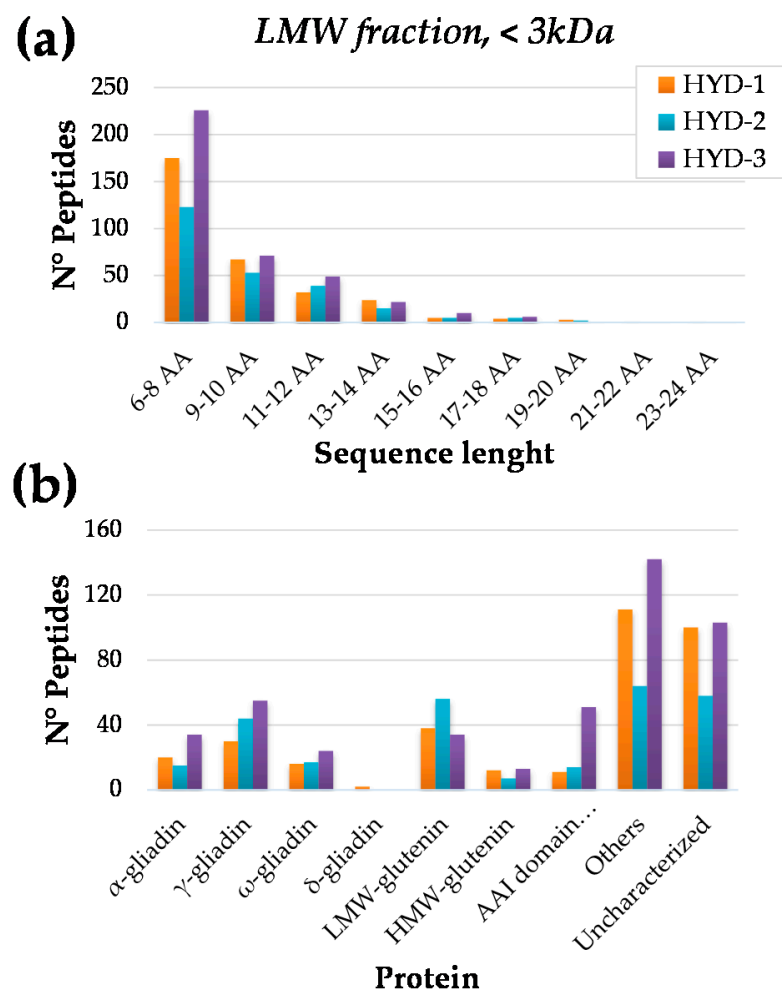

Figure 2. Overview of the peptides identified in the low molecular weight fraction (LMW, $<3 \mathrm{kDa}$ ) by the HR-MS/MS analysis. Panel (a): peptide count according to the sequence length. Panel (b): peptide count according to the belonging protein (please consider that several peptides were shared among different accessions).

These latter two classes of proteins were not taken into consideration for further discussion because they were not relevant for the $\mathrm{CD}$ immunoreactivity perspective. Interestingly, all of the storage proteins, namely gliadins $\left(\alpha-, \gamma_{-}, \omega_{-}, \delta\right.$-type) and glutenin (low molecular weight, LMW and high molecular weight, HMW) were affected, to a certain extent, by the microbial/enzymatic degradation. Of particular interest was the ability to hydrolyze $\alpha$ - and $\gamma$-gliadins, especially in the sample HYD-3, as they are mainly responsible for the toxicity level of durum wheat flours towards CD patients. In addition, the protein accessions referred to as 'AAI domain-containing proteins' were counted as an independent category because they featured partial sequence homology with $\gamma$-gliadin, $\alpha$-gliadin, and LMW-glutenin accessions, and thus deserved attention for the toxicity risk evaluation.

Such an evaluation was accounted for by an in-silico assessment of the sequence identity with known T-cell epitopes [27] by means of the CELIAC Database v.2 and the relevant tool for protein risk assessment (http://www.allergenonline.org/celiacfasta.shtml). All of the peptides detected in the LMW fractions were searched for an exact match with the immunostimulatory sequences, and the positive matches were counted in Table 2. Notably, only a few sequences from $\gamma$-gliadins (featuring partial sequence homology with $\omega$-gliadins) included intact epitopes, and they were detected only in sample HYD-2 and HYD-3, whereas no intact epitope was found in sample HYD-1.

In order to investigate further the protein degradation accounted for by the sourdough fermentation with the mixture of L. strains and fungal proteases, the high molecular weight (HMW) fraction of the protein extracts was also characterized by untargeted HR-MS/MS analysis. A typical workflow for a bottom-up proteomic approach, with chymotrypsin as specific enzyme, was applied to both the HYD and CTRL samples, keeping the latter as the internal reference to trace back to the susceptible and resistant sequences. Hundreds of sequences ascribed to Triticum taxonomies were identified in all 
of the samples, especially in the protein extract from the CTRL prototype breads (see Table 2 for the specific counting). Again, the difference in the number of detected peptides can likely be ascribed to the protein degradation occurring during the flours' fermentation, as this step was the only difference in the production of the HYD and CTRL samples. All of the identified peptides were screened for an exact match with known T-cell epitopes, as was previously described, after filtering out all of the sequences lower than $9 \mathrm{AA}$ in length. As was expected, the three control samples encoded for several tens of intact T-cell epitopes, which were differently distributed among the main storage proteins (see Table 2). Interestingly, protein accessions generally described as AAI domain-containing proteins (A0A446IHC0; A0A446IHA8, B6UKQ6, etc.) actually coded for full length epitopes; indeed, 8, 11, and 21 hazard peptides were detected in samples CTRL-1, CTRL-2, and CTRL-3, respectively (see Table 2). Notably, no intact epitope was detected in the HMW-fraction of sample HYD-1, and only one hazard peptide was detected in the HMW-fraction of HYD-3, proving that the detoxification strategy was very efficient for these two flours, degrading almost completely the epitopes coded by each genotype down to concentration levels below the sensitivity of this analytical method (see Table 2). On the contrary, a very different result was obtained for the HMW-fraction of the HYD-2 sample, in which most of the epitopes detected in the CTRL-2 sample were resistant to the proteolytic activity of the selected L. strains and peptidases involved in the fermentation process.

The untargeted HR-MS/MS analysis that was carried out proved unequivocally that — notwithstanding that the fermentation was equally applied to all three flours-its efficacy in gluten detoxification was dramatically different according to the specific genotype. Since all three genotypes were systematically characterized in our previous investigation [25], and were all promising in terms of reduced gluten content and potential lower toxicity, such differential behavior upon subjection to the fermentation can only find explanation in punctual differences of the protein primary structure that affects their susceptibility to hydrolysis by microbial/fungal proteases. According to this speculation, we carefully evaluated the list of peptides containing intact epitopes and grouped them based on the specific epitope that was coded. In addition, we also disclosed, whenever available, the relevant restricted 9 AA core epitope according to the current nomenclature proposed by Sollid et al. 2020 [49], in order to streamline the reading and understanding of the results. Indeed, most of the detected epitopes, which referred to different identification numbers in the CELIAC Database actually shared the same core 9 AA epitope, and thus likely presented similar binding efficiency to HLA-DQ antigens. Finally, thanks to the parallel analysis carried out on the control samples of each genotype, we furtherly deepened the data analysis by classifying the detected epitopes as 'resistant' or 'susceptible' to the fermentation process applied. Namely, the resistant epitopes were the ones identified in either the LMW or HMW fraction of the processed breads (HYD), whereas the susceptible epitopes were the sequences detected in any of the CTRL samples, but that were missing in the relevant HYD sample, thus suggesting its likely hydrolysis by the fermentation. Tables 3 and 4 present the results of such a data analysis, reporting the susceptible and resistant epitopes, respectively. The epitopes were listed according to the identification numbers assigned to them by the CD database (http://www.allergenonline.org/celiachome.shtml) and some further information about toxicity and the HLA-DQ antigen, as well as the number of peptides per sample encrypting the specific epitope. As was already mentioned, the possibility to identify the peptide sequences by searching against the reference proteome of durum wheat provided an undeniable advance for the current investigation. Browsing the list of the identified epitopes (see Tables 3 and 4), several sequences encrypting the 9AA-cores DQ2.5-glia- $\alpha 1 b$, DQ2.5-glia- $\alpha 2$, DQ8-glia- $\alpha 1$,a DQ2.5-glia- $\gamma 4 b$, expected to be coded only by the D genome, were detected [50]. Therefore, this proteomic investigation represents - to the best of our knowledge - the first experimental evidence that such epitopic sequences can also be expressed in tetraploid wheats. 
Table 3. List of the CD epitopes identified in the prototype breads (CTRL) that were susceptible to the proteolysis carried out by the selected strains of L. strains and fungal enzymes; none of them were detected in the HYD samples. The sequence reported in bold and underlined represents the 9AA core T-cell-activating epitope, according to Sollid et al. 2020 [49]. The human leucocyte antigen (HLA) was reported whenever specified.

\begin{tabular}{|c|c|c|c|c|c|c|c|c|}
\hline \multicolumn{6}{|c|}{ Epitopes Search * } & \multicolumn{3}{|c|}{$\mathbf{N}^{\circ}$ of Hazard Peptides/Sample ${ }^{* *}$} \\
\hline ID & Type & Toxicity *** & HLA-DQ & Sequence & Core T-Cell Epitope & CTRL-1 & CTRL-2 & CTRL-3 \\
\hline 55 & $\alpha$-gliadin & I & DQ2 & PQPQLPYPQPQLPY & DQ2.5-glia- $\alpha 1 b, D Q 2.5$-glia- $\alpha 2$ & 0 & 1 & 1 \\
\hline 64 & $\alpha$-gliadin & I & DQ2 & PQPQLPYPQPQL & DQ2.5-glia- $\alpha 2$ & 0 & 1 & 1 \\
\hline 66 & $\alpha$-gliadin & I & DQ2 & $\overline{\text { PQPQLPYPQPQ }}$ & DQ2.5-glia- $\alpha 2$ & 0 & 1 & 1 \\
\hline 68 & $\alpha-2$ gliadin & I & DQ2.5 & PQPQLPYPQ & DQ2.5-glia- $\alpha 2$ & 0 & 1 & 1 \\
\hline 72 & $\alpha$-gliadin & I & DQ2 & PQLPYPQPQLPY & DQ2.5-glia- $\alpha 1 b$ & 0 & 1 & 1 \\
\hline 84 & $\alpha-3$ gliadin & I & DQ2.5 & PYPQPQLPY & DQ2.5-glia- $\alpha 1 b$ & 0 & 1 & 1 \\
\hline 93 & $\alpha-20$ gliadin & I & DQ2.5 & $\overline{\text { FRPQQPYPQ }}$ & DQ2.5-glia- $\alpha 3$ & 1 & 1 & 1 \\
\hline 119 & $\alpha$-gliadin & I & DQ8 & GSFQPSQQNPQĀQGS & & 0 & 1 & 0 \\
\hline 140 & $\alpha$-gliadin & I & DQ8 & QLIPCMDVVL & & 1 & 0 & 1 \\
\hline 182 & $\alpha$-gliadin & I & DQ2 & LQPFPQPQPFLPQLPYPQPQ & & 1 & 1 & 1 \\
\hline 188 & $\alpha$-gliadin & I & DQ22 & FPGQQQ̄QFPPQQPYPQPQPF & & 1 & 0 & 1 \\
\hline 221 & $\omega$-II gliadin & I & DQ2 & PQPQQPFPW & DQ2.5-glia- $\omega 2$ & 0 & 1 & 0 \\
\hline 222 & $\omega$-gliadin & I & DQ2 & PFPWQPQQPFPQ & & 1 & 1 & 0 \\
\hline 226 & $\omega$-gliadin & I & DQ2 & QQPQQPFPQPQLPFPQ̄QSEQ & DQ2.5-glia- $\gamma 4 \mathrm{c} / \mathrm{DQ} 8$-glia- $\gamma 1 \mathrm{a}$ & 1 & 1 & 0 \\
\hline 231 & $\omega$-gliadin & I & DQ2 & PFPQPQQPIPV & & 1 & 1 & 1 \\
\hline 236 & $\omega$-gliadin & I & DQ22 & PFPLQPQQPFPQ & DQ2.5-glia- $\gamma 4 \mathrm{e}$ & 0 & 0 & 1 \\
\hline 463 & $\gamma$-gliadin & I & DQ8 (DQ2/8) & QQPYPQQPQQPFPQ & DQ2.5-glia- $\gamma 4$ c/DQ8-glia- $\gamma 1 \mathrm{a}$ & 0 & 1 & 1 \\
\hline 501 & $\gamma 1$-gliadin & I & DQ2 & PQQPFPQPQQTFPQQPQ̄LPF & & 0 & 0 & 1 \\
\hline 502 & $\gamma 1$-gliadin & I & DQ2, DQ8 & PFPQPQQTFPQQPQLPFPQQ & & 0 & 0 & 1 \\
\hline 504 & $\gamma 1$-gliadin & I & DQ2 & PQQTFPQQPQLP & & 0 & 0 & 1 \\
\hline 523 & $\gamma 1$-gliadin & I & DQ22 & QQPQQSFPQQQ & DQ2.5-glia- $\gamma 1 / \mathrm{DQ} 8.5$-glia- $\gamma 1 / \mathrm{DQ} 8$-glia- $\gamma 2$ & 21 & 3 & 1 \\
\hline 524 & $\gamma 1$-gliadin & I & DQ2 & QPQQSFPQQQ & DQ2.5-glia- $\gamma 1 / \mathrm{DQ} 8.5$-glia- $\gamma 1 / \mathrm{DQ} 8$-glia- $\gamma 2$ & 2 & 3 & 1 \\
\hline 530 & $\gamma$-gliadin & I & DQ8 (DQ2/8) & QFPQTQQQPQQPFPQ & DQ2.5-glia- $\gamma 4 \mathrm{c} / \mathrm{DQ} 8$-glia- $\gamma 1 \mathrm{a}$ & 0 & 0 & 1 \\
\hline 536 & $\gamma$-gliadin & I & DQ2, DQ8 & QQPQLPFP $\overline{Q Q P Q Q P F P Q P Q Q}$ & DQ2.5-glia- $\gamma 4 \mathrm{c} / \mathrm{DQ} 8$-glia- $\gamma 1 \mathrm{a}$ & 1 & 0 & 0 \\
\hline 537 & $\gamma$-gliadin & I & DQ8 (DQ2/8) & QLPFP $\overline{\mathrm{QQPQQPFPQ}}$ & DQ2.5-glia- $\gamma 4 \mathrm{c} / \mathrm{DQ} 8$-glia- $\gamma 1 \mathrm{a}$ & 1 & 2 & 0 \\
\hline 573 & $\gamma$-gliadin & I & DQ2 & FPQPQQQQFPQPQ & DQ2.5-glia- $\gamma 4 \mathrm{~b}$ & 0 & 0 & 1 \\
\hline 577 & $\gamma$-gliadin & I & DQ2.5 & $\overline{\text { PQPQQQFPQ }}$ & DQ2.5-glia- $\gamma 4 \mathrm{~b}$ & 0 & 0 & 1 \\
\hline 583 & $\gamma-1$ gliadin & I & DQ2.5/DQ8 & $\overline{\text { PQQSFPQQQ }}$ & DQ2.5-glia- $\gamma 1 / \mathrm{DQ} 8.5$-glia- $\gamma 1 / \mathrm{DQ} 8$-glia- $\gamma 2$ & $2 \quad 2$ & 4 & 2 \\
\hline 611 & $\gamma$-gliadin & I & DQ2 (DQ2.5) & PHQPQQQQVPQPQQPQQPF & & 0 & 1 & 0 \\
\hline 617 & $\gamma$-gliadin & I & DQ8 (DQ2/8) & PFPQLQQPQQPFPQ & DQ2.5-glia- $\gamma 4 \mathrm{c} / \mathrm{DQ} 8$-glia- $\gamma 1 \mathrm{a}$ & 1 & 1 & 0 \\
\hline 640 & $\gamma$-gliadin & I & DQ2 & QPQQSFPQQQRP & DQ2.5-glia- $\gamma 1 / \mathrm{DQ} 8.5$-glia- $\gamma 1 / \mathrm{DQ} 8$-glia- $\gamma 2$ & 21 & 0 & 0 \\
\hline 721 & LMW glutenin & I & DQ2 & QQQQPPFSQQQQSPFSQQQQ & DQ2.5-glut-L2 & 1 & 1 & 1 \\
\hline 729 & LMW glutenin & I & DQ2 & QQPPFSQQQQSPFSQ & DQ2.5-glut-L2 & 2 & 1 & 1 \\
\hline 731 & LMW glutenin & I & DQ2 & QQPPFSQQQQSP & & 5 & 1 & 2 \\
\hline 733 & LMW glutenin & I & DQ22 & QPPFSQQQQSPFSQ & DQ2.5-glut-L2 & 3 & 2 & 1 \\
\hline
\end{tabular}


Table 3. Cont.

\begin{tabular}{|c|c|c|c|c|c|c|c|c|}
\hline \multicolumn{6}{|c|}{ Epitopes Search * } & \multicolumn{3}{|c|}{$\mathbf{N}^{\circ}$ of Hazard Peptides/Sample ** } \\
\hline ID & Type & Toxicity *** & HLA-DQ & Sequence & Core T-Cell Epitope & CTRL-1 & CTRL-2 & CTRL-3 \\
\hline 734 & LMW glutenin & I & DQ2 & PPFSQQQQSPFSQQQ & DQ2.5-glut-L2 & 2 & 1 & 1 \\
\hline 736 & LMW glutenin & I & DQ2 & PFSQQQQSPFSQQQQ & DQ2.5-glut-L2 & 2 & 1 & 1 \\
\hline 738 & LMW glutenin & I & DQ2 & PFSQQQQSPF & DQ2.5-glut-L2 & 6 & 2 & 2 \\
\hline 747 & glut-L2 & I & DQ2.5 & $\overline{\text { FSQQQQSPF }}$ & DQ2.5-glut-L2 & 6 & 2 & 2 \\
\hline 835 & Hordein & I & DQ2 & QPFPQPQQPFPL & DQ2.5-glia- $\omega 1$ & 1 & 1 & 1 \\
\hline 867 & hor-1 & I & DQ2.5 & $\overline{\text { PFPQPQQPF }}$ & DQ2.5-glia- $\omega 1$ & 1 & 1 & 4 \\
\hline 878 & Hordein & I & DQ2 & QPFPQPQQPFSW & DQ2.5-glia- $\omega 1$ & 0 & 0 & 1 \\
\hline 886 & $\gamma$-hordein & I & DQ2 & QQFPQPQQPFPQQP & DQ2.5-hor-2 & 0 & 0 & 1 \\
\hline 890 & $\gamma$-hordein & I & DQ2 & QQ $\overline{\mathrm{FPQPQQPFPQ}}$ & DQ2.5-hor-2 & 0 & 0 & 1 \\
\hline 891 & hor-2 & I & DQ2.5 & PQPQQPFPQ & DQ2.5-hor-2 & 0 & 1 & 3 \\
\hline 930 & $\gamma$-secalin & I & DQ2 & QSIPQPQQPFPQ & DQ2.5-hor-2 & 0 & 0 & 1 \\
\hline 950 & $\omega$-Secalin & I & DQ2 & QPFPQPQQPIPQ & & 1 & 1 & 0 \\
\hline 973 & $\omega$-Secalin & I & DQ2 & IIPQQPQQPFPL & & 0 & 1 & 1 \\
\hline 1040 & glia- $\omega 3$ & I & DQ2.5 & PFPQPQQPI & & 2 & 2 & 1 \\
\hline 1042 & glia- $\omega 4$ & I & DQ2.5 & PQPQQPIPV & & 1 & 1 & 1 \\
\hline 1044 & glia- $\omega 5$ & I & DQ2.5 & LQPQQPFPQ & DQ2.5-glia- $\gamma 4 \mathrm{e}$ & 4 & 1 & 4 \\
\hline
\end{tabular}

* http://www.allergenonline.org/celiachome.shtml (Accessed on 1-3 April 2020). In the case of the glutamate residues (E) expected in-vivo by TG2-mediated deamidation, the respective sequence with unmodified glutamine $(\mathrm{Q})$ residue was searched. ** The number of peptides reported in brackets refers to the analysis of the LMW-fraction, whereas all of the other counts refer to the analysis of the HMW-fraction. ${ }^{* * *}$ I: immunogenic; T: toxic.

Table 4. List of CD epitopes identified in the prototype breads from the hydrolyzed flours (HYD) that were resistant to the proteolysis carried out by the selected strains of L. strains and fungal enzymes. The sequence reported in bold and underlined represents the 9AA core T-cell activating epitope, according to Sollid et al. 2020 [49].

\begin{tabular}{|c|c|c|c|c|c|c|c|c|}
\hline \multicolumn{6}{|c|}{ Epitopes Search * } & \multicolumn{3}{|c|}{$\mathbf{N}^{\circ}$ of Hazard Peptides/Sample ** } \\
\hline ID & Type & Toxicity *** & HLA-DQ & Epitope Sequence & Core T-Cell Epitope & HYD-1 & HYD-2 & HYD-3 \\
\hline 1 & $\alpha$-gliadin & $\mathrm{T}$ & Unknown & VPVPQLQPQNPSQQQPQEQVPL & - & 0 & 1 & 0 \\
\hline 3 & $\alpha$-gliadin & I & DQ2 & VRVPVPQLQPQNPSQQQPQ & - & 0 & 1 & 0 \\
\hline 5 & $\alpha$-gliadin & I & DQ2 & FPGQQQPFPPQQPYPQPQPF & - & 0 & 1 & 0 \\
\hline 7 & $\alpha$-gliadin & $\mathrm{I}, \mathrm{T}$ & HLA-DR & PQPQPFPSQQPY & - & 0 & 3 & 0 \\
\hline 14 & $\alpha$-gliadin & I & DQ2 & LQLQPFPQPQLPY & DQ2.5-glia- $\alpha 1 \mathrm{a}$ & 0 & 1 & 0 \\
\hline 24 & $\alpha$-gliadin & I & DQ2 & QLQPFPQPQLPY & DQ2.5-glia- $\alpha 1 \mathrm{a}$ & 0 & 1 & 0 \\
\hline 32 & $\gamma$-gliadin & I & DQ2 & PQQ $\overline{P F P Q P Q Q}$ & DQ2.5-glia- $\gamma 5$ & 0 & 0 & $0(1)$ \\
\hline 36 & $\alpha$-gliadin & I & DQ2 & $\widehat{\overline{Q Q P F P Q P Q L P Y}}$ & DQ2.5-glia- $\alpha 1 \mathrm{a}$ & 0 & 1 & 0 \\
\hline 42 & $\alpha$-gliadin & I & DQ2 & QPFPQPQLPY & DQ2.5-glia- $\alpha 1 \mathrm{a}$ & 0 & 1 & 0 \\
\hline 53 & $\alpha-9$ gliadin & I & DQ2.5 & PFPQPQLPY & DQ2.5-glia- $\alpha 1 \mathrm{a}$ & 0 & 1 & 0 \\
\hline
\end{tabular}


Table 4. Cont

\begin{tabular}{|c|c|c|c|c|c|c|c|c|}
\hline \multicolumn{6}{|c|}{ Epitopes Search * } & \multicolumn{3}{|c|}{$\mathbf{N}^{\circ}$ of Hazard Peptides/Sample ** } \\
\hline ID & Type & Toxicity *** & HLA-DQ & Epitope Sequence & Core T-Cell Epitope & HYD-1 & HYD-2 & HYD-3 \\
\hline 95 & $\alpha$-gliadin & I & $\begin{array}{l}\text { DQ8 (DQ2/8, } \\
\text { DQ1/8) }\end{array}$ & QQPQQQYPSGQGSFQPSQQNPQAQG & DQ8-glia- $\alpha 1$ & 0 & 1 & 0 \\
\hline 96 & $\alpha$-gliadin & I & DQ8 & QQPQQQYPSGQGSFQPSQQNPQAQ & DQ8-glia- $\alpha 1$ & 0 & 1 & 0 \\
\hline 100 & $\alpha$-gliadin & I & DQ8 & QPQQQYPSGQGSFQPSQQNP & DQ8-glia- $\alpha 1$ & 0 & 1 & 0 \\
\hline 101 & $\alpha$-gliadin & I & $\begin{array}{l}\text { DQ8 (DQ2/8, } \\
\text { DQ1/8) }\end{array}$ & QQYPSGQGSFQPSQQNPQ & DQ8-glia- $\alpha 1$ & 0 & 1 & 0 \\
\hline 102 & $\alpha$-gliadin & I & DQ8 & QYPSGQGSFQPSQQNPQA & DQ8-glia- $\alpha 1$ & 0 & 1 & 0 \\
\hline 104 & $\alpha$-gliadin & I & DQ8 & YPSGQGSFQPSQQNP & DQ8-glia- $\alpha 1$ & 0 & 1 & 0 \\
\hline 105 & $\alpha$-gliadin & I & DQ8 (DQ2/8) & PSGQGSFQPSQQNPQAQG & DQ8-glia- $\alpha 1$ & 0 & 1 & 0 \\
\hline 106 & $\alpha$-gliadin & I & DQ8 (DQ2/8) & PSGQGSFQPSQQ & DQ8-glia- $\alpha 1$ & 0 & 1 & 0 \\
\hline 107 & $\alpha$-gliadin & I & DQ8 (DQ2/8) & PSGQGGSQPSQ & - & 0 & 1 & 0 \\
\hline 108 & $\alpha$-gliadin & I & DQ8 (DQ2/8) & SGQGSFQPSQQN & DQ8-glia- $\alpha 1$ & 0 & 1 & 0 \\
\hline 113 & $\alpha$-gliadin & I & DQ8 (DQ2/8) & $\widehat{\overline{G Q G S F Q P S Q}}$ & - & 0 & 1 & 0 \\
\hline 115 & $\alpha 2$ gliadin & I & DQ8 (DQ2/8) & QGSFQPSQQ & DQ8-glia- $\alpha 1$ & 0 & 1 & 0 \\
\hline 138 & $\alpha$-gliadin & I & DQ2 & PिQPYPQPQPQ & - & 0 & 1 & 0 \\
\hline 146 & $\alpha$-gliadin & I & DQ2 & QVPLVQQQQFLGQQQPFPPQ & - & 0 & 1 & 0 \\
\hline 149 & $\alpha$-gliadin & $\mathrm{I}, \mathrm{T}$ & Unknown & LGQQQPFPPQQPYPQPQPFPSQQPY & - & 0 & 1 & 0 \\
\hline 150 & $\alpha$-gliadin & $\mathrm{I}, \mathrm{T}$ & $\begin{array}{c}\mathrm{DQ} 2\left(\alpha 1^{*} 0501\right. \\
\left.\alpha 1^{*} 0201\right)\end{array}$ & LGQQQPFPPQQPYPQPQPF & - & 0 & 1 & 0 \\
\hline 151 & $\alpha$-gliadin & I & $\begin{array}{l}\mathrm{DQ} 2\left(\alpha 1^{*} 0501\right. \\
\left.\alpha 1^{*} 0201\right)\end{array}$ & LGQQQPFPPQQPYPQPQ & - & 0 & 1 & 0 \\
\hline 152 & $\alpha$-gliadin & $\mathrm{I}, \mathrm{T}$ & HLA-DR & LGQQQPFPPQQPY & - & 0 & 2 & 0 \\
\hline 185 & $\alpha$-gliadin & I & DQ2 & QPQPFLPQLPYPQP & - & 0 & 1 & 0 \\
\hline 187 & $\alpha$-gliadin & I & DQ2 & PQPFLPQLPYPQ & - & 0 & 1 & 0 \\
\hline 195 & $\omega$-gliadin & I & DQ2 & PQQPFPQQPQQP & DQ2.5-glia- $\gamma 5$ & 0 & $2(2)$ & 0 \\
\hline 227 & $\omega$-gliadin & I & DQ2 & $\overline{\text { QPFPQPQLPFPQ }}$ & & 0 & 1 & 0 \\
\hline 229 & $\omega$-gliadin & I & DQ2 & PFPQQPQQPFPQ & DQ2.5-glia- $\gamma 4 \mathrm{c} / \mathrm{DQ} 8$-glia- $\gamma 1 \mathrm{a}$ & 0 & $3(1)$ & $0(1)$ \\
\hline 246 & $\begin{array}{l}\omega 5 \text {-gliadin/LMW } \\
\text { glutenin }\end{array}$ & I & DQ2 & QQQQIPQQPQQF & - & 0 & 1 & 0 \\
\hline 252 & $\begin{array}{l}\omega 5 \text {-gliadin/LMW } \\
\text { glutenin }\end{array}$ & I & DQ2 & QIPQQPQQF & - & 0 & 2 & 0 \\
\hline 426 & $\gamma$-gliadin & I & DQ2 & PQQPFPQQPQQPYPQQP & $\begin{array}{c}\text { DQ2.5-glia- } \gamma 3 / \mathrm{DQ} 8 \text {-glia- } \gamma 1 \mathrm{~b}, \\
\text { DQ2.5-glia- } \gamma 5\end{array}$ & 0 & 1 & 0 \\
\hline 427 & $\gamma$-gliadin & I & DQ2 & PQQPFPQQPQQPY & DQ2.5-glia- $\gamma 5$ & 0 & 1 & 0 \\
\hline 432 & $\gamma$-gliadin & I & DQ2 & PQQPFPQQPQQ & DQ2.5-glia- $\gamma 5$ & 0 & $2(2)$ & 0 \\
\hline 437 & $\gamma$-gliadin & I & DQ2 & QQPFPQQPQQPYPQ & $\begin{array}{c}\text { DQ2.5-glia- } \gamma 3 / \text { DQ8-glia- } \gamma 1 \mathrm{~b}, \\
\text { DQ2.5-glia- } \gamma 5\end{array}$ & 0 & 1 & 0 \\
\hline 438 & $\gamma 5$ gliadin & I & DQ2.5 & QQPFPQQPQ & DQ2.5-glia- $\gamma 5$ & 0 & $4(2)$ & $0(1)$ \\
\hline
\end{tabular}


Table 4. Cont

\begin{tabular}{|c|c|c|c|c|c|c|c|c|}
\hline \multicolumn{6}{|c|}{ Epitopes Search * } & \multicolumn{3}{|c|}{$\mathbf{N}^{\circ}$ of Hazard Peptides/Sample ** } \\
\hline ID & Type & Toxicity*** & HLA-DQ & Epitope Sequence & Core T-Cell Epitope & HYD-1 & HYD-2 & HYD-3 \\
\hline 441 & $\gamma$-gliadin & I & DQ2 & PFPQQPQQPYPQQPQ & DQ2.5-glia- $\gamma 3 / \mathrm{DQ} 8$-glia- $\gamma 1 \mathrm{~b}$ & 0 & 1 & 0 \\
\hline 445 & $\gamma$-gliadin & I & DQ2 & PFPQQPQQPYPQ & DQ2.5-glia- $\gamma 3 / \mathrm{DQ} 8$-glia- $\gamma 1 \mathrm{~b}$ & 0 & 1 & 0 \\
\hline 446 & $\gamma$-gliadin & I & DQ8, DQ2 & FPQQPिQPPYPQQPQQ & DQ2.5-glia- $\gamma 3 / \mathrm{DQ} 8$-glia- $\gamma 1 \mathrm{~b}$ & 0 & 1 & 0 \\
\hline 451 & $\gamma$-gliadin & I & DQ2 & FPQQPQQPYPQQP & DQ2.5-glia- $\gamma 3 / \mathrm{DQ} 8$-glia- $\gamma 1 \mathrm{~b}$ & 0 & 1 & 0 \\
\hline 454 & $\gamma$-gliadin & I & DQ2 & FPQQPQQPYPQQ & DQ2.5-glia- $\gamma 3 / \mathrm{DQ} 8$-glia- $\gamma 1 \mathrm{~b}$ & 0 & 1 & 0 \\
\hline 458 & $\gamma 1$ and $\gamma 5$ gliadin & I & DQ2.5/DQ8 & $\widehat{\text { QQPQQPYPQ }}$ & DQ2.5-glia- $\gamma 3 /$ DQ8-glia- $\gamma 1 \mathrm{~b}$ & 0 & $2(1)$ & $0(1)$ \\
\hline 464 & $\gamma$-gliadin & I & DQ2 & $\widehat{\mathrm{QQPYPQQPQ}}$ & 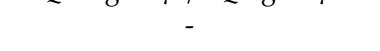 & 0 & $1(1)$ & $0(1)$ \\
\hline 468 & $\gamma$-gliadin & I & $\begin{array}{l}\mathrm{DQ} 2(\mathrm{DQ} 2.2 \text { and } \\
\text { DQ2.5) }\end{array}$ & PYPQQPQQP & - & 0 & 1 & 0 \\
\hline 472 & $\gamma$-gliadin & I & DQ2.5/DQ8 & QQPQQPFPQ & DQ2.5-glia- $\gamma 4 c / D Q 8$-glia- $\gamma 1 \mathrm{a}$ & 0 & $8(4)$ & $0(4)$ \\
\hline 479 & $\gamma 1$-gliadin & I & DQ2 & QVDPSGQVQWPQ & - & 0 & 3 & 0 \\
\hline 503 & $\gamma 1$-gliadin & I & DQ2 & PFPQPQQTFPQ & - & 0 & 1 & 0 \\
\hline 538 & $\gamma$-gliadin & I & DQ2 & PFPQQPQQPF & - & 0 & $3(1)$ & $0(1)$ \\
\hline 542 & $\gamma$-gliadin & I & DQ2 & FPQQPQQPF & - & 0 & $4(1)$ & $0(1)$ \\
\hline 553 & $\gamma$-gliadin & I & DQ8 (DQ2/8) & PFPQTQQPQQPFPQ & DQ2.5-glia- $\gamma 4 c / D Q 8-$ glia- $\gamma 1 \mathrm{a}$ & 0 & 1 & 0 \\
\hline 555 & $\gamma$-gliadin & I & DQ8 (DQ2/8) & PFPQSQ & DQ2.5-glia- $\gamma 4 \mathrm{c} / \mathrm{DQ} 8$-glia- $\gamma 1 \mathrm{a}$ & 0 & 1 & 0 \\
\hline 587 & $\gamma$-gliadin & I & DQ2 & VQGQGIIQPQQPAQL & DQ2.5-glia- $\gamma 2$ & 0 & $3(1)$ & 0 \\
\hline 593 & $\gamma$-gliadin & I & DQ2 & GIIQPQQPAQL & DQ2.5-glia- $\gamma 2$ & 0 & $4(1)$ & 0 \\
\hline 595 & $\gamma$-gliadin & I & DQ2 & IIQPQQPAQL & DQ2.5-glia- $\gamma 2$ & 0 & $4(1)$ & 0 \\
\hline 597 & $\gamma$-gliadin & I & DQ2 & $\overline{\text { IIQPQQPAQ }}$ & - & 0 & $6(1)$ & 0 \\
\hline 599 & $\gamma 5$ gliadin & I & DQ2.5 & IQPQQPAQL & DQ2.5-glia- $\gamma 2$ & 0 & $4(1)$ & 0 \\
\hline 612 & $\gamma$-gliadin & I & DQ8 (DQ2/8) & $\underline{\text { QQPFPQQPQQPFPQ }}$ & $\begin{array}{l}\text { DQ2.5-glia- } \gamma 4 \mathrm{c} / \mathrm{DQ} 8 \text {-glia- } \gamma 1 \mathrm{a}, \\
\text { DQ2.5-glia- } \gamma 5\end{array}$ & 0 & $3(1)$ & 0 \\
\hline 650 & $\gamma$-gliadin & I & DQ2 & QPFPQLQQPQQP & -1 & 0 & 1 & 0 \\
\hline 659 & LMW glutenin & I & DQ2 & QAFPQPQQTFPH & - & 0 & 1 & 0 \\
\hline 701 & $\begin{array}{l}\gamma \text {-gliadin or LMW } \\
\text { glutenin }\end{array}$ & I & DQ2 & QQPPFSQQQQPVLPQ & DQ2.5-glut-L1/DQ2.2-glut-L1 & 0 & 3 & 0 \\
\hline 706 & Glut-L1 & I & DQ2.2 & PFSQQQQPV & DQ2.5-glut-L1/DQ2.2-glut-L1 & 0 & 7 & 0 \\
\hline 720 & LMW glutenin & I & DQ2 & QQPिFSQQQQPPFSQ & 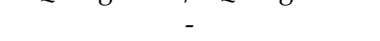 & 0 & 2 & 0 \\
\hline 762 & LMW glutenin & I & DQ2 & QQPPFSQQQQQPILL & - & 0 & 1 & 0 \\
\hline 763 & LMW glutenin & I & DQ2 & QPPFSQQQQQPILL & - & 0 & 1 & 0 \\
\hline 781 & HMW-Glutenin & I & DQ8 (DQ2/8) & GQPGYYPTSPQQPGQ & - & 0 & 1 & 0 \\
\hline 903 & Secalin & I & DQ2 & PQQSFPQQP & - & 0 & 0 & 1 \\
\hline 926 & $\gamma$-secalin & I & DQ2 & PQTQQPQQPFPQ & DQ2.5-glia- $\gamma 4 \mathrm{c} / \mathrm{DQ} 8$-glia- $\gamma 1 \mathrm{a}$ & 0 & 1 & 0 \\
\hline 928 & $\gamma$-secalin & I & DQ2 & PQSQิQQPQQPFPQ & DQ2.5-glia- $\gamma 4 \mathrm{c} / \mathrm{DQ} 8$-glia- $\gamma 1 \mathrm{a}$ & 0 & 1 & 0 \\
\hline
\end{tabular}

In the case of the glutamate residues (E) expected in-vivo by TG2-mediated deamidation, the respective sequence with unmodified refer to the analysis of the HMW-fraction. ${ }^{* * *} \mathrm{I}$ : immunogenic; T: toxic. 
Assessing whether the detoxification strategy provided the efficient degradation of the specific DQ2.5 and/or DQ8 epitopes boasts great relevance from the general perspective, because CD patients may express foremost either one. Indeed, approximately 95\% of CD patients express HLA-DQ2.5 antigens, which are then statistically more relevant for the susceptible population, whereas the rest are usually either HLA-DQ8 positive, or, to a minor extent, express HLA antigens that contain only one of the DQ2.5-chains, e.g., DQ2.2 or DQ7.5 [49,51]. In addition, although polyclonal T-cell recognizing multiple epitopes are usually detected in CD patients, specific responses to the DQ2.5-glia- $\alpha 1$, DQ2.5-glia- $\alpha 2$ epitopes, and homologues thereof ( $\omega$-gliadins, hordeins and secalins) are dominant in DQ2.5-positive patients, and responses to the DQ8-glia- $\alpha 1$ epitope are most frequently found in DQ8-positive patients [27].

Notably, the current investigation proved that the devised protocol for gluten detoxification enabled the efficient degradation of the main core epitopes DQ2.5-glia- $\alpha 1 b$, DQ2.5-glia- $\alpha 2$, DQ2.5-glia- $\alpha 3$, DQ2.5-glia- $\omega 1$, DQ2.5-glia- $\omega 2$, and DQ2.5-hor-2, which are differently expressed in the three genotypes under investigation (see Table 3); moreover, under the same fermentation conditions, the core epitopes DQ2.5-glia- $\gamma 1 / D Q 8.5$-glia- $\gamma 1$, DQ2.5-glia- $\gamma 4 \mathrm{~b}$, and DQ2.5-glut-L2 were completely hydrolysed. In addition, from a further analysis of the list reported in Table 3, it was found that also the DQ2 epitopes with ID numbers $182,188,222,231,236,501,502,504,611,731,950,973,1040,1042$, and 1044, and the DQ8 epitopes with ID numbers 119, 140, 502, and 611 were all completely susceptible to the detoxification applied. On the contrary, the epitopes containing the core sequences DQ2.5-glia- $\gamma 4 \mathrm{c} / \mathrm{DQ8}$-glia- $\gamma 1 \mathrm{a}$ (shared sequence) presented only a partial susceptibility to the hydrolysis, depending on the specific ID number (see Tables 3 and 4). Finally, in Table 4, all of the alternative full-length epitopes that survived the fermentation process, which were still detectable in the hydrolysed sample, were reported. Most of these resistant epitopes were actually found only in the HYD-2 sample, since, as was already mentioned, no T-cell activating sequence was detected in the HYD-1 protein sample (neither in the LMW nor in the HMW fractions), and only few peptides were found in the HYD-3 sample. In particular, the epitopes containing the cores DQ2.5-glia- $\alpha 1$ a, DQ8-glia- $\alpha 1$, DQ2.5-glia- $\gamma 2$, DQ2.5-glia- $\gamma 3 / D Q 8$-glia- $\gamma 1 b$, DQ2.5-glia- $\gamma 5$, and DQ2.5-glut-L1 were proven to be resistant to the hydrolysis, together with several other epitopic sequences belonging mainly to $\alpha$-gliadins, and less so to $\gamma$-gliadin, $\omega$-gliadin, and glutenin (see Table 4 for the full list).

\subsection{In Vitro-Simulated Human Gastroduodenal Digestion Experiments and In-Silico Evaluation of the Toxicity Risk for Celiac Disease Patients}

As a final step, the two prototype breads of main interest, HYD-1 and HYD-3, which were shown to be GF and low-gluten content, respectively, by immunoassays, were subjected to in-vitro simulated human gastroduodenal (GD) digestion experiments. The aim was to evaluate the digestibility and toxicity risk for $\mathrm{CD}$ patients of the hydrolyzed gluten proteins in such processed samples, in experimental conditions, which simulate the human GD digestion process. The standardized static protocol applied [30] provided all of the technical details required simulating in-vitro the three main steps of the physiological process, namely the oral, gastric and duodenal phases. The protein digestion was assessed only at the end point of the whole process; after the $2 \mathrm{~h}$ incubation occurring in the duodenal phase, the procedure was stopped with phenylmethyl sulfonyl fluoride, and the peptide pools were purified by solid phase extraction on disposable cartridges. The resulting purified samples were characterized by untargeted HR MS/MS analysis, as described in the experimental section. The software-based identification was performed with the same database applied to the previous proteomic investigation by setting an unspecific cleavage for the peptide sequence assignments, due to the high complexity of the enzyme mixtures involved into the human GD process.

Notably, the final lists of peptide sequences assigned to triticum-belonging proteins was quite short; only 291 peptides for the GD digest of bread HYD-1, and 227 peptides for the GD digest of bread HYD-3. This proved that the extensive hydrolysis affected the wheat proteins after the combined effect of the detoxifying strategy and the GD digestion process. Moreover, an in-depth analysis of the 
data acquired showed that, in both cases, most of the peptides detected were below the 9 AA length cut-off, and thus do not pose a risk to elicit any immune-response in CD patients. In particular, only 79 peptides out of the 291 detected for the HYD-1 bread were greater than or equal to 9 AA in length. Similarly, only 71 peptides out of the 227 detected were greater than or equal to 9 AA in length for the HYD-3 bread.

These short lists of sequences were screened against the CELIAC Database, as previously described, in order to disclose the presence of epitopic sequences that were resistant to the detoxification process applied and survived the GD digestion, as well. Notably, no epitope was detected in the GD digests of both the HYD-1 and HYD-3 breads. This experimental evidence confirmed that the detoxification strategy applied to these two prototype samples was successful in hydrolyzing the toxic/immunogenic sequences expressed in the relevant monovarietal flours down to concentration levels thar become not detectable in the in-vitro simulated human GD digests.

\section{Conclusions}

In this investigation, we reported the production of prototype GF breads from processed flours of specific Triticum turgidum wheat genotypes, which were subjected to sourdough fermentation with a mixture of selected Lactobacillus strains and fungal endoproteases. The immunoassay-based characterization suggested a differential efficiency in the gluten degradation according to the specific monovarietal flour, which was investigated in-depth by HR mass spectrometry and in-silico epitope mapping. The in-vitro simulated human GD experiments also proved the absence of toxic/immunogenic epitopes that are relevant for CD patients in the prototype breads produced, confirming the relevance of this investigation for the improvement of the dietary habits of vulnerable individuals. Notably, the advanced proteomic analysis provided new insight for the development of detoxification strategies assessing a genotype-depending efficiency of the proteolytic activity strictly related to the punctual differences of the primary protein structure. Taking advantage of the full sequencing of the durum wheat genome, a detailed list of the susceptible and resistant epitopic sequences was achieved in the current investigation, suggesting the need to constrain the validity of any detoxification strategy to the specific flours on which they are developed.

Author Contributions: Conceptualization, R.P., M.D.A., G.M. and L.M.; Data curation, R.P.; Formal analysis, R.P., A.L. and E.D.A.; Funding acquisition, R.P. and L.M.; Methodology, R.P., M.D.A., A.L., E.D.A., C.G.R. and S.S.; Resources, A.G.; Writing-original draft, R.P. and S.S.; Writing—review and editing, R.P., M.D.A., C.G.R., A.G., G.M. and L.M. All authors have read and agreed to the published version of the manuscript.

Funding: This research was funded by the Ministry of Education, Universities and Research (MIUR-Italy), program SIR 2014, within the project titled "S. Wheat Pro. - Proteomic characterization of Selected durum Wheat cultivars for PROduction of low toxicity-food products towards celiac disease patients (RBSI14QQ1W)".

Acknowledgments: The Authors are thankful to Francesco De Marzo, Domenico Genchi and Roberto Schena for the technical assistance, and to Mariella Quarto for the administrative help.

Conflicts of Interest: The authors declare no conflict of interest.

\section{References}

1. Ribeiro, M.; Nunes, F.M. We might have got it wrong: Modern wheat is not more toxic for celiac patients. Food Chem. 2019, 278, 820-822. [CrossRef]

2. Ribeiro, M.; Rodríguez-Quijano, M.; Nunes, F.M.; Carrillo, J.M.; Branlard, G.; Igrejas, G. New insights into wheat toxicity: Breeding did not seem to contribute to a prevalence of potential celiac disease's immunostimulatory epitopes. Food Chem. 2016, 213, 8-18. [CrossRef]

3. Pilolli, R.; Gadaleta, A.; Mamone, G.; Nigro, D.; De Angelis, E.; Montemurro, N.; Monaci, L. Scouting for naturally low-toxicity wheat genotypes by a multidisciplinary approach. Sci. Rep. 2019, 9, 1-15. [CrossRef]

4. Escarnot, E.; Gofflot, S.; Sinnaeve, G.; Dubois, B.; Bertin, P.; Mingeot, D. Reactivity of gluten proteins from spelt and bread wheat accessions towards A1 and G12 antibodies in the framework of celiac disease. Food Chem. 2018, 268, 522-532. [CrossRef] 
5. Malalgoda, M.; Meinhardt, S.W.; Simsek, S. Detection and quantitation of immunogenic epitopes related to celiac disease in historical and modern hard red spring wheat cultivars. Food Chem. 2018, 264, 101-107. [CrossRef]

6. Prandi, B.; Tedeschi, T.; Folloni, S.; Galaverna, G.; Sforza, S. Peptides from gluten digestion: A comparison between old and modern wheat varieties. Food Res. Int. 2017, 91, 92-102. [CrossRef]

7. Schalk, K.; Lang, C.; Wieser, H.; Koehler, P.; Scherf, K.A. Quantitation of the immunodominant 33-mer peptide from $\alpha$-gliadin in wheat flours by liquid chromatography tandem mass spectrometry. Sci. Rep. 2017, 7, 45092. [CrossRef]

8. De Santis, M.A.; Giuliani, M.M.; Giuzio, L.; De Vita, P.; Lovegrove, A.; Shewry, P.R.; Flagella, Z. Differences in gluten protein composition between old and modern durum wheat genotypes in relation to 20th century breeding in Italy. Eur. J. Agron. 2017, 87, 19-29. [CrossRef]

9. Picascia, S.; Camarca, A.; Malamisura, M.; Mandile, R.; Galatola, M.; Cielo, D.; Gazza, L.; Mamone, G.; Auricchio, S.; Troncone, R.; et al. In celiac disease patients the in vivo challenge with the diploid Triticum monococcum elicits a reduced immune response compared to hexaploid wheat. Mol. Nutr. Food Res. 2020, 64, e1901032. [CrossRef]

10. Jouanin, A.; Gilissen, L.W.J.; Boyd, L.A.; Cockram, J.; Leigh, F.J.; Wallington, E.J.; van den Broeck, H.C.; van der Meer, I.M.; Schaart, J.G.; Visser, R.G.F.; et al. Food processing and breeding strategies for coeliac-safe and healthy wheat products. Food Res. Int. 2018, 110, 11-21. [CrossRef]

11. Gianfrani, C.; Camarca, A.; Mazzarella, G.; Di Stasio, L.; Giardullo, N.; Ferranti, P.; Picariello, G.; Aufiero, V.R.; Picascia, S.; Troncone, R.; et al. Extensive in vitro gastrointestinal digestion markedly reduces the immune-toxicity of Triticum monococcum wheat: Implication for celiac disease. Mol. Nutr. Food Res. 2015, 59, 1844-1854. [CrossRef] [PubMed]

12. Boukid, F.; Mejri, M.; Pellegrini, N.; Sforza, S.; Prandi, B. How looking for celiac-safe wheat can influence its technological properties. Compr. Rev. Food Sci. Food Saf. 2017, 16, 797-807. [CrossRef]

13. Goesaert, H.; Brijs, K.; Veraverbeke, W.; Courtin, C.; Gebruers, K.; Delcour, J.A. Wheat flour constituents: How they impact bread quality, and how to impact their functionality. Trends Food Sci. Technol. 2005, 16, 12-30. [CrossRef]

14. Ribeiro, M.; Nunes, F.M.; Rodríguez-Quijano, M.; Carrillo, J.M.; Branlard, G.; Igrejas, G. Next-generation therapies for celiac disease: The gluten-targeted approaches. Trends Food Sci. Technol. 2018, 75, 56-71. [CrossRef]

15. Luongo, D.; Maurano, F.; Bergamo, P.; Rossi, M. Microbial transglutaminase: A biotechnological tool to manage gluten intolerance. Anal. Biochem. 2020, 592, 113584. [CrossRef] [PubMed]

16. Gobbetti, M.; Pontonio, E.; Filannino, P.; Rizzello, C.G.; De Angelis, M.; Di Cagno, R. How to improve the gluten-free diet: The state of the art from a food science perspective. Food Res. Int. 2018, 110, 22-32. [CrossRef] [PubMed]

17. Rai, S.; Kaur, A.; Chopra, C.S. Gluten-free products for celiac susceptible people. Front. Nutr. 2018, 5, 116. [CrossRef] [PubMed]

18. Gianfrani, C.; Siciliano, R.A.; Facchiano, A.M.; Camarca, A.; Mazzeo, M.F.; Costantini, S.; Salvati, V.M.; Maurano, F.; Mazzarella, G.; Iaquinto, G.; et al. Transamidation of wheat flour inhibits the response to gliadin of intestinal T cells in celiac disease. Gastroenterology 2007, 133, 780-789. [CrossRef]

19. Sharma, N.; Bhatia, S.; Chunduri, V.; Kaur, S.; Sharma, S.; Kapoor, P.; Kumari, A.; Garg, M. Pathogenesis of celiac disease and other gluten related disorders in wheat and strategies for mitigating them. Front. Nutr. 2020, 7, 6. [CrossRef] [PubMed]

20. Wei, G.; Helmerhorst, E.J.; Darwish, G.; Blumenkranz, G.; Schuppan, D. Gluten degrading enzymes for treatment of celiac disease. Nutrients 2020, 12, 2095. [CrossRef]

21. De Angelis, M.; Rizzello, C.G.; Fasano, A.; Clemente, M.G.; De Simone, C.; Silano, M.; De Vincenzi, M.; Losito, I.; Gobbetti, M. VSL\#3 probiotic preparation has the capacity to hydrolyze gliadin polypeptides responsible for Celiac Sprue probiotics and gluten intolerance. Biochim. Biophys. Acta Mol. Basis Dis. 2006, 1762, 80-93. [CrossRef]

22. Gerez, C.L.; Dallagnol, A.; Rollán, G.; Font de Valdez, G. A combination of two lactic acid bacteria improves the hydrolysis of gliadin during wheat dough fermentation. Food Microbiol. 2012, 32, 427-430. [CrossRef] 
23. Di Cagno, R.; De Angelis, M.; Lavermicocca, P.; De Vincenzi, M.; Giovannini, C.; Faccia, M.; Gobbetti, M. Proteolysis by sourdough lactic acid bacteria: Effects on wheat flour protein fractions and gliadin peptides involved in human cereal intolerance. Appl. Environ. Microbiol. 2002, 68, 623-633. [CrossRef]

24. Di Cagno, R.; De Angelis, M.; Auricchio, S.; Greco, L.; Clarke, C.; De Vincenzi, M.; Giovannini, C.; D'Archivio, M.; Landolfo, F.; Parrilli, G.; et al. Sourdough bread made from wheat and nontoxic flours and started with selected lactobacilli is tolerated in celiac sprue patients. Appl. Environ. Microbiol. 2004, 70, 1088-1096. [CrossRef]

25. Pilolli, R.; Gadaleta, A.; Di Stasio, L.; Lamonaca, A.; De Angelis, E.; Nigro, D.; De Angelis, M.; Mamone, G.; Monaci, L. A Comprehensive peptidomic approach to characterize the protein profile of selected durum wheat genotypes: Implication for coeliac disease and wheat allergy. Nutrients 2019, 11, 2321. [CrossRef]

26. Colgrave, M.L.; Goswami, H.; Byrne, K.; Blundell, M.; Howitt, C.A.; Tanner, G.J. Proteomic profiling of 16 cereal grains and the application of targeted proteomics to detect wheat contamination. J. Proteome Res. 2015, 14, 2659-2668. [CrossRef]

27. Naegeli, H.; Birch, A.N.; Casacuberta, J.; De Schrijver, A.; Gralak, M.A.; Guerche, P.; Jones, H.; Manachini, B.; Messéan, A.; Nielsen, E.E.; et al. Guidance on allergenicity assessment of genetically modified plants. EFSA J. 2017, 15, 04862. [CrossRef]

28. Maccaferri, M.; Harris, N.S.; Twardziok, S.O.; Pasam, R.K.; Gundlach, H.; Spannagl, M.; Ormanbekova, D.; Lux, T.; Prade, V.M.; Milner, S.G.; et al. Durum wheat genome highlights past domestication signatures and future improvement targets. Nat. Genet. 2019, 51, 885-895. [CrossRef]

29. Pilolli, R.; De Angelis, E.; Monaci, L. In house validation of a high resolution mass spectrometry Orbitrap-based method for multiple allergen detection in a processed model food. Anal. Bioanal. Chem. 2018, 410, 5653-5662. [CrossRef]

30. Minekus, M.; Alminger, M.; Alvito, P.; Ballance, S.; Bohn, T.; Bourlieu, C.; Carrière, F.; Boutrou, R.; Corredig, M.; Dupont, D.; et al. A standardised staticin vitrodigestion method suitable for food-An international consensus. Food Funct. 2014, 5, 1113-1124. [CrossRef]

31. Fiorda, F.A.; Soares, M.S.; Da Silva, F.A.; Grosmann, M.V.; Souto, L.R. Microestructure, texture and colour of gluten-free pasta made with amaranth flour, cassava starch and cassava bagasse. LWT 2013, 54, 132-138. [CrossRef]

32. Sandhu, K.S.; Kaur, M. Mukesh Studies on noodle quality of potato and rice starches and their blends in relation to their physicochemical, pasting and gel textural properties. LWT 2010, 43, 1289-1293. [CrossRef]

33. Hager, A.-S.; Wolter, A.; Czerny, M.; Bez, J.; Zannini, E.; Arendt, E.K.; Czerny, M. Investigation of product quality, sensory profile and ultrastructure of breads made from a range of commercial gluten-free flours compared to their wheat counterparts. Eur. Food Res. Technol. 2012, 235, 333-344. [CrossRef]

34. Kadan, R.; Robinson, M.G.; Thibodeaux, D.P.; Pepperman, A.B. Texture and other physicochemical properties of whole rice bread. J. Food Sci. 2006, 66, 940-944. [CrossRef]

35. See, J.A.; Kaukinen, K.; Makharia, G.K.; Gibson, P.R.; Murray, J.A. Practical insights into gluten-free diets. Nat. Rev. Gastroenterol. Hepatol. 2015, 12, 580-591. [CrossRef]

36. Rizzello, C.G.; Montemurro, M.; Gobbetti, M. Characterization of the bread made with durum wheat semolina rendered gluten free by sourdough biotechnology in comparison with commercial gluten-free products. J. Food Sci. 2016, 81, H2263-H2272. [CrossRef]

37. Calvo-Lerma, J.; Crespo-Escobar, P.; Martínez-Barona, S.; Fornés-Ferrer, V.; Donat, E.; Ribes-Koninckx, C. Differences in the macronutrient and dietary fibre profile of gluten-free products as compared to their gluten-containing counterparts. Eur. J. Clin. Nutr. 2019, 73, 930-936. [CrossRef]

38. Papillo, V.A.; Agostoni, C. Nutritional aspects of gluten-free products. J. Sci. Food Agric. 2015, 95, $2380-2385$. [CrossRef]

39. Rizzello, C.G.; De Angelis, M.; Di Cagno, R.; Camarca, A.; Silano, M.; Losito, I.; De Vincenzi, M.; De Bari, M.D.; Palmisano, F.; Maurano, F.; et al. Highly efficient gluten degradation by lactobacilli and fungal proteases during food processing: New perspectives for celiac disease. Appl. Environ. Microbiol. 2007, 73, 4499-4507. [CrossRef]

40. De Angelis, M.; Cassone, A.; Rizzello, C.G.; Gagliardi, F.; Minervini, F.; Calasso, M.; Di Cagno, R.; Francavilla, R.; Gobbetti, M. Mechanism of degradation of immunogenic gluten epitopes from Triticum turgidum L. var. durum by sourdough lactobacilli and fungal proteases. Appl. Environ. Microbiol. 2009, 76, 508-518. [CrossRef] 
41. Di Cagno, R.; Barbato, M.; Di Camillo, C.; Rizzello, C.G.; De Angelis, M.; Giuliani, G.; De Vincenzi, M.; Gobbetti, M.; Cucchiara, S. Gluten-free sourdough wheat baked goods appear safe for young celiac patients: A pilot study. J. Pediatr. Gastroenterol. Nutr. 2010, 51,777-783. [CrossRef]

42. Greco, L.; Gobbetti, M.; Auricchio, R.; Di Mase, R.; Landolfo, F.; Paparo, F.; Di Cagno, R.; De Angelis, M.; Rizzello, C.G.; Cassone, A.; et al. Safety for patients with celiac disease of baked goods made of wheat flour hydrolyzed during food processing. Clin. Gastroenterol. Hepatol. 2011, 9, 24-29. [CrossRef]

43. Curiel, J.A.; Coda, R.; Limitone, A.; Katina, K.; Raulio, M.; Giuliani, G.; Rizzello, C.G.; Gobbetti, M. Manufacture and characterization of pasta made with wheat flour rendered gluten-free using fungal proteases and selected sourdough lactic acid bacteria. J. Cereal Sci. 2014, 59, 79-87. [CrossRef]

44. Giuliani, G.; Benedusi, A.; Di Cagno, R.; Rizzello, C.G.; De Angelis, M.; Gobbetti, M.; Cassone, A. Process of Microbic Biotechnology for Completely Degrading Gluten in Flours. W.O. Patent 2010073283-A2, 1 July 2010.

45. Kunji, E.R.; Mierau, I.; Hagting, A.; Poolman, B.; Konings, W.N. The proteotytic systems of lactic acid bacteria. Antonie Leeuwenhoek 1996, 70, 187-221. [CrossRef]

46. Collin, P.; Thorell, L.; Kaukinen, K.; Mäki, M. The safe threshold for gluten contamination in gluten-free products. Can trace amounts be accepted in the treatment of coeliac disease? Aliment. Pharmacol. Ther. 2004, 19, 1277-1283. [CrossRef]

47. European Commission. Commission Regulation (EC) No. 41/2009 concerning the composition and labelling of foodstuffs suitable for people intolerant to gluten. Off. J. Eur. Union 2009, 16, 3-5.

48. Panda, R.; Garber, E.A.E. Detection and quantitation of gluten in fermented-hydrolyzed foods by antibody-based methods: Challenges, progress, and a potential path forward. Front. Nutr. 2019, 6, 97. [CrossRef] [PubMed]

49. Sollid, L.M.; Tye-Din, J.A.; Qiao, S.-W.; Anderson, R.P.; Gianfrani, C.; Koning, F. Update 2020: Nomenclature and listing of celiac disease-relevant gluten epitopes recognized by CD4+ T cells. Immunogenetics 2019, 72, 85-88. [CrossRef]

50. Wang, D.; Li, D.; Wang, J.; Zhao, Y.; Wang, Z.; Yue, G.; Liu, X.; Qin, H.; Zhang, K.; Dong, L.; et al. Genome-wide analysis of complex wheat gliadins, the dominant carriers of celiac disease epitopes. Sci. Rep. 2017, 7, 44609. [CrossRef]

51. Karell, K.; Louka, A.S.; Moodie, S.J.; Ascher, H.; Clot, F.; Greco, L.; Ciclitira, P.J.; Sollid, L.M.; Partanen, J. Hla types in celiac disease patients not carrying the DQA1*05-DQB1*02 (DQ2) heterodimer: Results from the European genetics cluster on celiac disease. Hum. Immunol. 2003, 64, 469-477. [CrossRef]

Publisher's Note: MDPI stays neutral with regard to jurisdictional claims in published maps and institutional affiliations.

(C) 2020 by the authors. Licensee MDPI, Basel, Switzerland. This article is an open access article distributed under the terms and conditions of the Creative Commons Attribution (CC BY) license (http://creativecommons.org/licenses/by/4.0/). 